\title{
THE IMPACT OF TROPICAL DEFORESTATION ON RIVER CHEMICAL POLLUTION
}

\section{F. BENAVIDES ${ }^{1, *}$ J.N. VEENSTRA ${ }^{2}$}

\author{
${ }^{1}$ Environmental Science Graduate Program, \\ Oklahoma State University, \\ 40 s. University pl. \# 8, Stillwate ok 74075, USA \\ ${ }^{2}$ School of Civil and Environmental Engineering, \\ Oklahoma State University, \\ 107 ES, Stillwater, OK 74078, USA.
}

Selected from papers presented in $9^{\text {th }}$ International Conference on Environmental Science and Technology (9CEST2005)

1-3 September 2005, Rhodes island, Greece *to whom all correspondence should be addressed

Tel:+1 8017434638

e-mail: francisco.benavides@okstate.edu

\begin{abstract}
The objective of this study was to provide a quantitative description of the impact of converting tropical forests into pastures for cattle grazing in terms of the sediment, nitrogen and phosphorus concentrations at the outlet of a river basin located in North West Costa Rica. The Soil and Water Assessment Tool (SWAT) was utilized to model the watershed. The graphs for pollutant concentration vs. percent area of the watershed under pasture showed a monotonic increase in concentrations as deforestation increased. Contaminant levels for the entire watershed as grassland were between 3 and 8 times higher than for the total area as forest, which could put at risk the drinking water supply and the tourism-based economy of the region. Keeping the current percentage of area under grassland constant, but restricting pastures to the less fragile and more fertile lands could decrease the sediment, nitrogen and phosphorus concentrations at the main watershed outlet by more than $35 \%, 12 \%$ and $21 \%$, respectively, as compared to the predicted pollutant concentrations for the current land cover distribution. The effect of varying cattle stocking rates resulted in lower sediment and nitrogen run-off for areas with higher animal loads in which confined operations are used part of the year.
\end{abstract}

KEYWORDS: hydrologic modeling, watershed management, water pollution, SWAT, Costa Rica.

\section{INTRODUCTION}

Tropical forests have been disappearing over the years as a consequence of unsustainable natural resource exploitation, imposing a threat against biodiversity conservation, clean drinking water supplies, and climate stability (Ramírez, 2000). The purpose of this study was to model quantitatively the extent to which the conversion of forests into pastures can degrade the quality of surface water, as determined by the concentrations of sediment, phosphorus, and nitrogen, in a watershed located in NorthWest Costa Rica. Deforestation in that country has been driven primarily by the expansion of grassland to raise cattle, in part to satisfy international beef markets. Other tropical nations facing challenging deforestation dilemmas, like Brazil, attribute most of their forest loss to the same phenomenon (Brown, 1990). 
The Nosara watershed was chosen for the study because: 1 ) pasture and forest in that area share several borders and they are currently the dominant land uses; 2) the expansion of grassland into forested land is feasible (part of the forest is on flat terrain and it is not under a strict preservation status); 3) the area is accessible and therefore allows for a good understanding of how land is managed; 4) the watershed and its associated receiving body (the Pacific Ocean) have significant and diverse economic activities, including tourism, agriculture, and fishing, making the case more relevant for future multi-disciplinary work; and 5) the largest ranches in the country are located there and at the same time the area has some of the major reforestation projects underway.

The project utilized the Soil and Water Assessment Tool (SWAT) to estimate the concentration of the three pollutants at the outlet of the river basin under different ratios of forest to pasture within the watershed. The use of SWAT in developing countries is a fairly recent and infrequent occurrence (Barsanti et al., 2003). The present study is not only unique for being centered in a tropical and developing country, where deforestation is a critical issue, but it is also novel in that it specifically investigates the impact of converting increasing amounts of land from forest into pasture, allowing for a quantitative estimation of river water quality under several hypothetical scenarios, including the relocation of grasslands to areas of low erodibility, and the use of different cattle stocking rates.

\section{MATERIALS AND METHODS}

SWAT is a hydrological model for river basins that has been widely and successfully used during the past decade (Arnold et al., 1998). To set-up the model, twenty years of daily maximum and minimum temperatures and rainfall going from 1984 through 2003 were obtained from the meteorological agency of Costa Rica (Instituto Meteorológico Nacional, 2003). More than $99.9 \%$ of the information was available, and missing data were taken as the average for the specific days for the period. Digital land cover and soils maps with a resolution of $30 \mathrm{~m} \times 30 \mathrm{~m}$ were also utilized (Ministerio de Agricultura y Ganadería, 1998; Ministerio de Ambiente y Energía, 1998). Soils were re-classified according to the US Natural Resources Conservation Service system and they were formatted for SWAT using published methods (Peschel et al., 2003). A digital elevation map with a resolution of $90 \mathrm{~m} \times 90 \mathrm{~m}$ was taken from the US Geological Survey (United States Geological Survey, 2004). Four pixels were missing and they were filled by taking an average of the elevation in the neighboring pixels.

The main basin outlet is the point where the Nosara river flows into the Pacific Ocean. The watershed has an area of $34,500 \mathrm{ha}$, an elevation that goes from sea level to $950 \mathrm{~m}$ above sea level, and a sub-tropical climate with a total average annual rainfall of 2150 $\mathrm{mm}$ and average maximum and minimum temperatures of $33^{\circ} \mathrm{C}$ and $21{ }^{\circ} \mathrm{C}$, respectively. Primary and secondary forests account for $52 \%$ of the area, while $47.5 \%$ is under pasture or range. The other $0.5 \%$ corresponds to urban areas, wetlands and permanent crops. The watershed was divided into 22 sub-basins and 116 hydrologic response units (HRUs). Figure 1 shows the land-cover map, sub-basins, and main channels. Details about grassland management practices in the area were obtained by directly interviewing several ranchers during August of 2004.

In terms of flow calibration, a study that includes four measurements in one stream within the basin was used to adjust the model by varying diverse parameters governing different processes of the hydrologic cycle (Ministerio de Agricultura y Ganadería, 1986). Figure 2 shows the points and line of best fit for a plot of predicted vs. measured flows after calibration, with a regression coefficient of 0.9886 .

The model was run for the baseline land cover, for the entire area in forest, and then as pasture, using different stocking rates. 


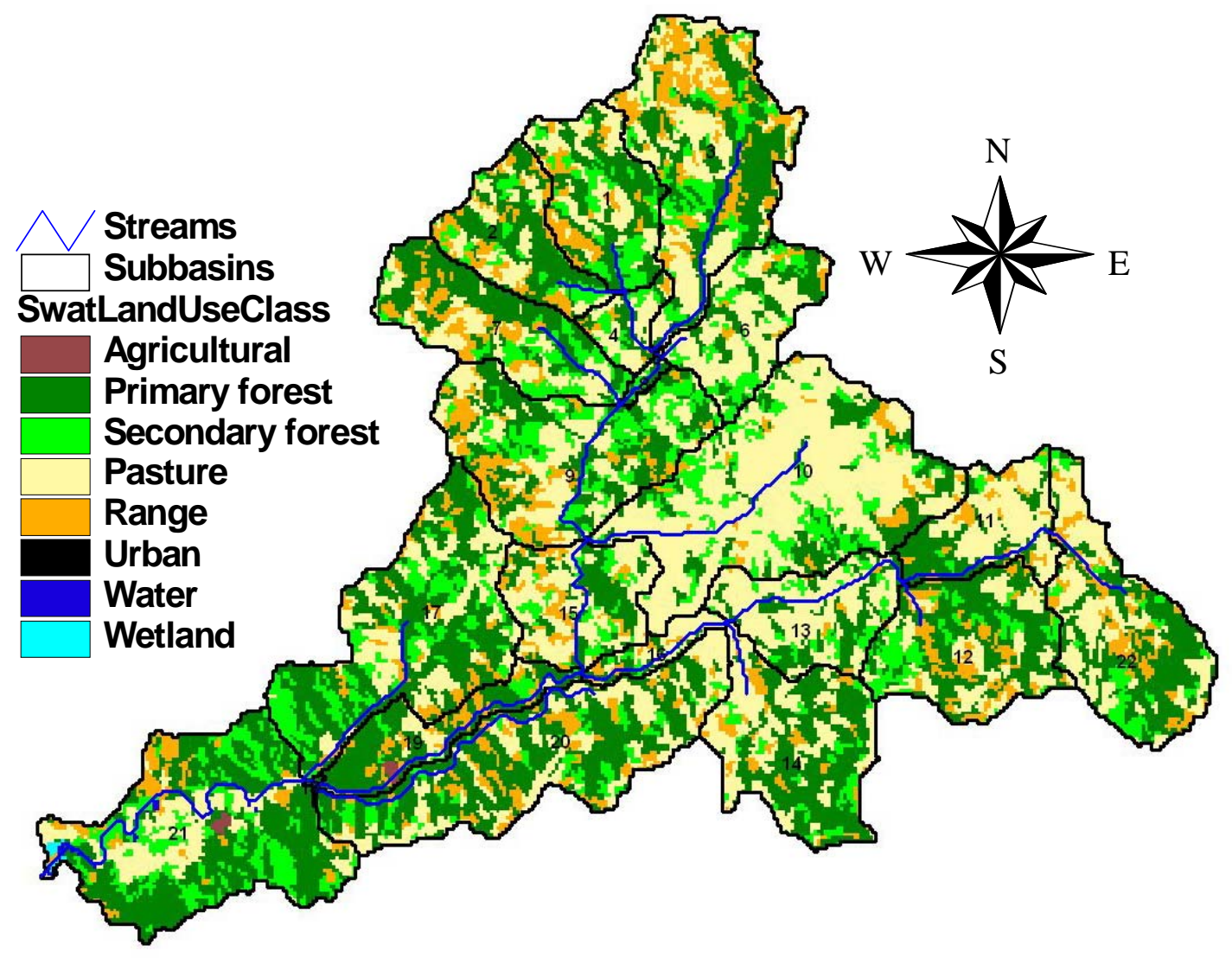

Figure 1. Land-cover map

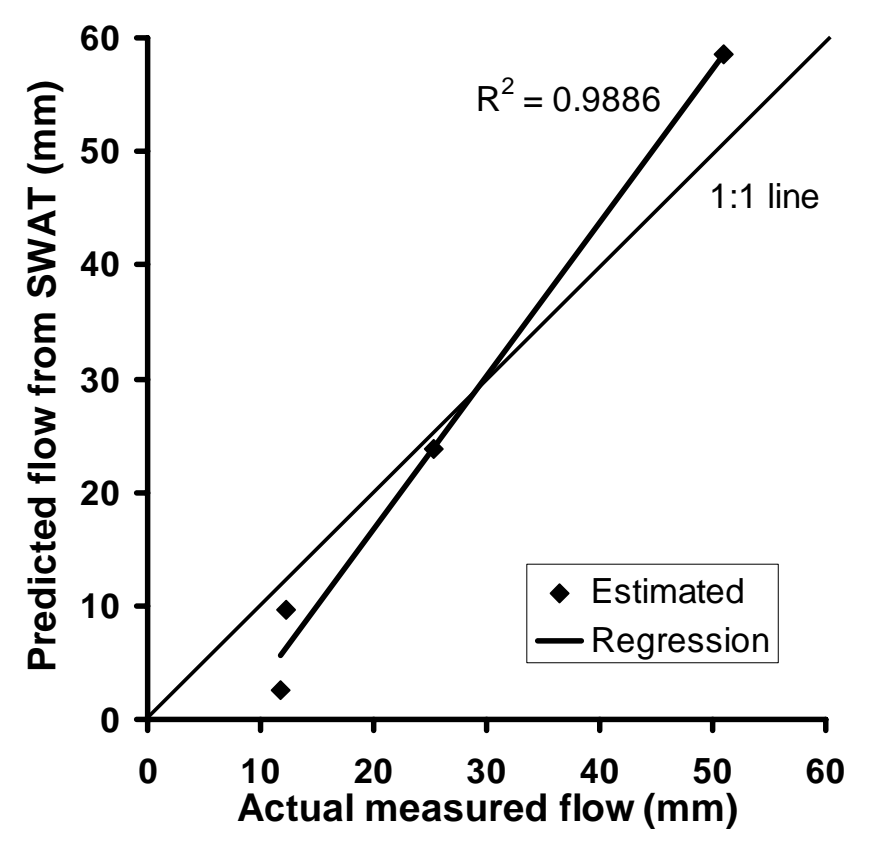

Figure 2. Model calibration 


\section{RESULTS AND DISCUSSION}

The baseline concentrations for sediment, nitrogen and phosphorus were $247 \mathrm{mg} \mathrm{l}^{-1}, 3.75$ $\mathrm{mg} \mathrm{l}^{-1}$ and $0.85 \mathrm{mg} \mathrm{l}^{-1}$, respectively. A comparison of the runs with the whole watershed as pasture and then as forest allowed for the ranking of the $116 \mathrm{HRUs}$ according to the predicted increase in sediment concentration when the HRU is deforested. Figures 3 through 5 show the result of that comparison, with the three graphs having the same HRU order

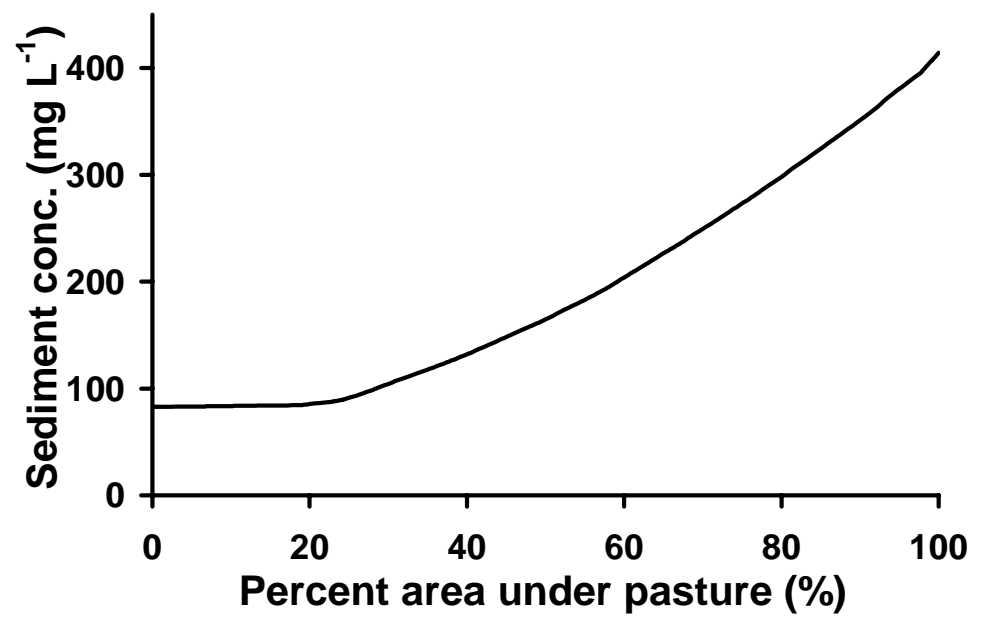

Figure 3. Effect of deforestation on the sediment concentration

The left of graph 3 corresponds to areas that increase the sediment concentration only marginally when they are converted from forest to pasture, while those on the right increase it to a larger extent. Pastures are more erodible than forests and cattle grazing, biomass trampling and manure deposition increase sediment run-off in different proportions for different combinations of soil type and slope.

Similar observations can be drawn from Figures 4 and 5 for the nitrogen and phosphorus concentrations. Sediment contains nutrients primarily in the organic and insoluble form, and therefore an increase in its concentration also tends to increase the concentration of total nitrogen and phosphorus. But even where deforestation does not increase sediment run-off, soluble nitrogen and phosphorus will increase with pasture conversion due to higher surface water flow. Pastures have higher water runoff because their rainfall interception rate is lower compared to forests, and because of soil compaction by cattle, which decreases soil permeability to water (Brooks, 1997).

Figures 3 through 5 suggest that going from a watershed that is totally forested to one that is totally under pasture would increase the concentration of sediment at the main outlet by approximately 5 times, the concentration of nitrogen by 3.5 times and the concentration of phosphorus 8 times. If the current area under pasture was relocated to the less erodible HRUs, the concentrations of sediment, nitrogen and phosphorus would be $156 \mathrm{mg} \mathrm{l}^{-1}, 3.27 \mathrm{mg} \mathrm{l}^{-1}$ and $0.67 \mathrm{mg} \mathrm{l}^{-1}$, respectively, as read from the graphs presented. That would result in decreases of $37 \%, 13 \%$ and $21 \%$, respectively, compared to the baseline simulation.

Figures 6 through 8 show the sediment, nitrogen and phosphorus concentrations when the entire area is pasture, for two sets of grazing parameters corresponding to two very different ways of managing pastures: a low stocking rate of 0.86 animals ha-1 and a high stocking rate of 3 animals ha ${ }^{-1}$. In the first case cattle are left to graze the entire year and during the dry season there is over-grazing and pasture almost disappears, with tracts of land turning into exposed bare soil. Sediment and nitrogen run-off are high under those conditions. 


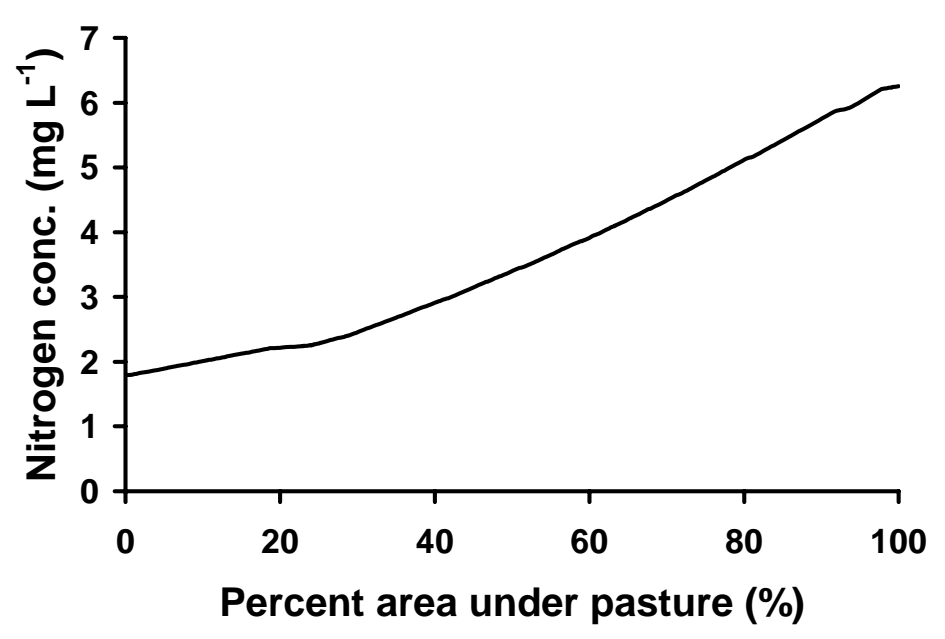

Figure 4. Effect of deforestation on the nitrogen concentration

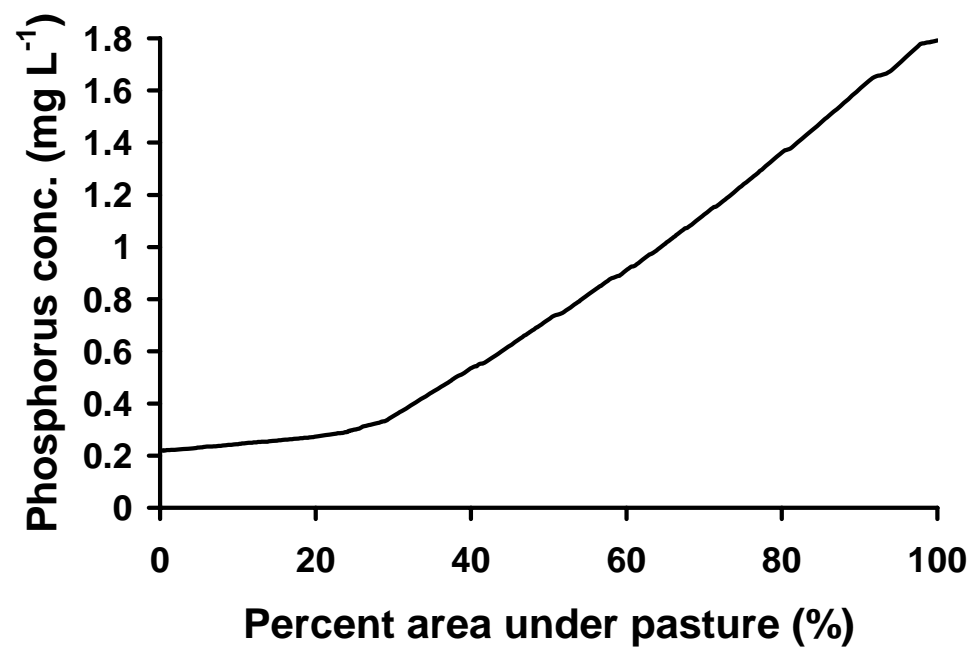

Figure 5. Effect of deforestation on the phosphorus concentration

The second case is representative of farms that have been influenced by the drive from the government of Costa Rica to promote agricultural intensification to improve productivity and earnings for the farmer. Ranches are divided into five areas were cattle graze one week at a time, allowing for higher grass (and cattle) yields. Animals are taken out of the pasture during the four months of dry season and they are placed in a confined feeding operation, which was not included in the model, to reflect the practice by many farmers of treating manure in lagoons or selling it as fertilizer.

Figures 6 and 7 show that the high stocking rate can actually decrease sediment concentration by $40 \%$ and nitrogen concentration by $11 \%$. Agricultural intensification in the watershed can result in lower pollutant loads.

According to Figure 8 , the phosphorus concentration varied only marginally from the first case to the second, due to the sensitivity of the model, the soils characteristics, and because that nutrient is always in excess in the system, independent of the duration or intensity of grazing. There were no phosphorus stress days in the simulation, while nitrogen was the limiting plant growth factor 86 days during the year on average. Even with a decrease in sediment run-off, more grazing translates into increased phosphorus deposition, at a rate higher than the uptake by plants. Fertilization is not used in the area 


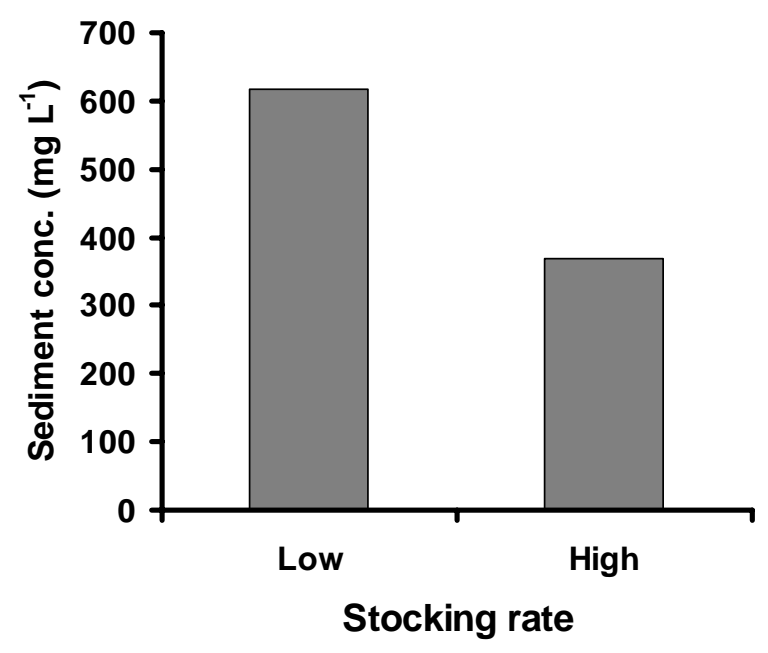

Figure 6. Effect of stocking rates on the sediment concentration

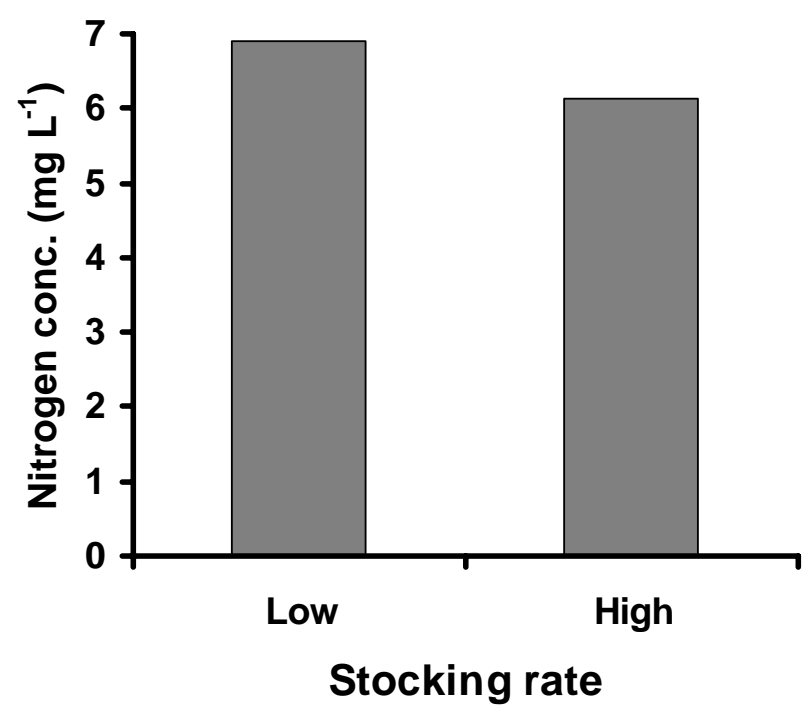

Figure 7. Effect of stocking rates on the nitrogen concentration

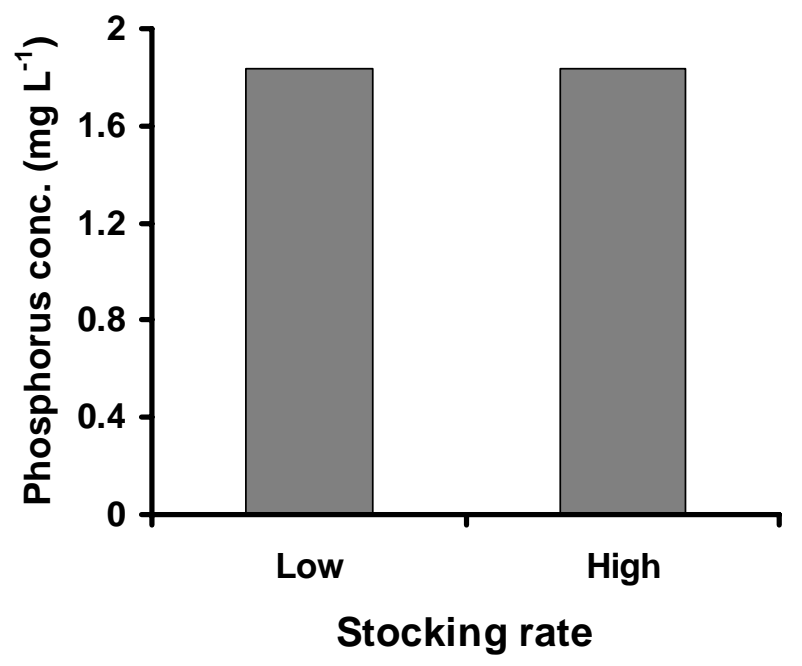

Figure 8. Effect of stocking rates on the phosphorus concentration 


\section{CONCLUSIONS}

The results of this study demonstrated that tropical deforestation can be accompanied by a significant increase in river chemical pollution. Studies in the US have recommended maximum concentrations of total suspended solids that go from $100 \mathrm{mg} \mathrm{l}^{-1}$ to $25 \mathrm{mg} \mathrm{l}^{-1}$ for recreational waters, primarily with the intention of protecting aquatic life (United States Environmental Protection Agency, 2005). The sediment concentration at the outlet of Nosara, both for the baseline simulation and for the case of total deforestation are significantly higher than those recommended maximum limits. Tourism is by far the most important industry of the area, and that economic activity could be negatively affected if deforestation-driven pollution is not controlled.

In the case of the total nitrogen concentrations, both the value for complete deforestation and for the baseline land cover are below the United States Environmental Protection Agency (USEPA) standard for drinking water of $11 \mathrm{mg} \mathrm{l}^{-1}$ (as total nitrogen), and the World Health Organization (WHO) standard for short exposure of $53 \mathrm{mg} \mathrm{l}^{-1}$, but the WHO establishes a maximum limit of only $0.2 \mathrm{mg} \mathrm{l}^{-1}$ for long term exposure (World Health Organization, 2004). Moreover, some of the HRUs generated total nitrogen concentrations of up to $10.4 \mathrm{mg} \mathrm{l}^{-1}$. In the watershed more than 2500 individuals take their drinking water directly from creeks and rivers with no treatment.

Phosphorus can cause eutrophication, and although general recommendations from the WHO or the USEPA do not exist in terms of maximum concentrations for recreational waters, the values estimated for Nosara are very high.

No measurements for river sediment and nutrient concentration in the watershed have been published, and therefore comparisons to reference data were not performed, suggesting that the specific absolute values predicted by the model should be used with prudence. In spite of that limitation, the ratios and percent changes estimated in the study showed that agricultural intensification can decrease river chemical pollution provided that manure is treated and/or removed from the watershed during the cattle confinement period. The project also proved that implementing policies that would restrict grasslands to the areas of lower erodibility can significantly decrease pollution, even if the total pasture area remains constant.

\section{ACKNOWLEDGMENTS}

The authors would like to thank Mike White, Bio-systems and Agricultural Engineering Department, and Dr. Brian Carter, Plant and Soil Sciences Department, at Oklahoma State University, for their valuable insights and contributions during the course of this project.

\section{REFERENCES}

Arnold, J.G., Srinivasan, R., Muttiah, R.S. and Williams, J.R. (1998), Large area hydrologic modeling and assessment part I: model development, Journal of the American Water Resources Association, 34, 73-89.

Barsanti, P., Disperati, L., Marri, P. and Mione, A. (2003), Soil erosion evaluation and multitemporal analysis in two Brazilian basins, Proceedings of the 2nd International SWAT Conference, Bari, Italy.

Brooks, K.N. (1997), Hydrology and the management of watersheds, lowa State University Press, Ames, lowa.

Brown, L.R. (1990), The illusion of progress. In: State of the world 1990, L. R. Brown (Ed.), Worldwatch Institute, Washington, D.C.

Instituto Meteorológico Nacional. (2003), Temperaturas máxima y mínimima para Guanacaste y Puntarenas, [CD-ROM], IMN, Costa Rica.

Ministerio de Agricultura y Ganadería. (1986), Plan de manejo de la cuenca superior del río Nosara, MAG, Costa Rica.

Ministerio de Agricultura y Ganadería. (1998), Mapa digital de capacidad de uso de la tierra, [CD Rom], MAG, Costa Rica.

Ministerio de Ambiente y Energía. (1998), Cobertura del Suelo 96-97, [CD-ROM], MINAE, Costa Rica. 
Peschel, J., Haan, P. and Lacey, R. (2003), A SSURGO pre-processing extension for the ArcView Soil and Water Assessment Tool, ASAE Annual International Meeting, Las Vegas, Nevada.

Ramírez, O.A. (2000), The carbon cycle and the value of forests as a carbon sink: a tropical case study, In: Sustainable forest management and global climate change: selected case studies from the Americas, M. H. I. Dore and R. Guevara (Eds.), Edward Elgar Publisher, Northampton.

United States Environmental Protection Agency. (2005), Office of Water, URL: http://www.epa.gov/OW/index.html, USEPA, Washington, DC (13 January 2005).

United States Geological Survey. (2004), Seamless data distribution system, URL: http://gisdata.usgs.net/website/Seamless/, USGS Eros Data Center, Sioux Falls, South Dakota (27 August 2004).

World Health Organization. (2004), Guidelines for Drinking Water Quality, URL: http://www.who.int/water sanitation health/dwq/gdwq3/en/, WHO, Geneva, Switzerland (2 December 2004). 